\title{
SUCCESS FACTORS FOR START-UPS RELATED TO AGRICULTURE, FOOD AND NUTRITION AND THEIR RELEVANCE TO EDUCATION
}

\author{
Helena Smolová ${ }^{1}$, Pavla Kubová1, Hana Urbancová \\ ${ }^{1}$ University of Economics and Management Prague, Nárožní 2600/9a, 15800 Praha 5, Czech Republic \\ ${ }^{2}$ Department of Territorial Development of Agriculture and Rural Areas, Division Research - Rural Development, \\ Institute of Agricultural Economics and Information, Mánesova 1453/75, 12000 Prague 2, Czech Republic
}

\begin{abstract}
SMOLOVÁ HELENA, KUBOVÁ PAVLA, URBANCOVÁ HANA. 2018. Success Factors for Start-ups Related to Agriculture, Food and Nutrition and Their Relevance to Education. Acta Universitatis Agriculturae et Silviculturae Mendelianae Brunensis, 66(3): 791-801.

Continuous formation of new businesses, start-ups, which could establish themselves on the market and be successful, should be supported in all economic areas, and the area of agriculture is no exception. Thus the main aim of this paper is to formulate a recommendation for educational institutions which prepare future generations, among others, to establish start-ups in agriculture that reflect fundamental success factors. The data were acquired with the aid of structured interviews $(n=6)$, which were carried out in electronic form. The respondents agreed that they considered the greatest obstacle, and at the same time challenge, to be the entry into the unknown, and that fear of failure in the context of an enterprise in the area of agriculture, food and nutrition has arrived only in the last few years, when loans, employees and obligations are on the rise.
\end{abstract}

Keywords: agriculture, food, nutrition, start-up, success factors

\section{INTRODUCTION}

The types of activities and order thereof which starting entrepreneurs perform have a significant influence on the ability successfully to form new businesses (Carter et al., 1996). In his article, Blank (2013) mentions a decades-old pattern - a business plan is compiled, it is presented to investors, a team is assembled, the product is presented and begins to be sold. The expression start-up first appeared in connection with newly-built companies in the 1970s, when the American magazine Forbes used it in one of its articles (1976). Kessler (2007, p. 381) asserts that this type of enterprise currently plays a very significant role in the formation and maintenance of a functioning market economy.

The main aim of this paper is to formulate a recommendation for educational institutions which prepare future generations, among others, to establish start-ups in agriculture that reflect fundamental success factors. A partial aim of this article is also to explain how these techniques and further trends can initiate new principles of business economics in agricultural businesses.

This survey was conducted by the University of Economics and Management, a. s. (VŠEM) in cooperation with the Czech Academy of Agricultural Sciences (CAAS) and it was discussed at the Ministry of Agriculture. The authors are aware of the small sample of the respondents in the survey in these specific business areas. Despite this, however, one cannot overlook the fact that to this day, no similar survey has been carried out in the conditions of Czech Republic, which is why the authors are of the impression that the acquired information can benefit not only other incipient entrepreneurs, but likewise secondary schools and higher education facilities in preparing their study plans.

In the part to follow, the cardinal term start-up is first defined theoretically, after which a presentation follows of theoretical departure points adumbrating the success factors for this type of enterprise according to selected professional authors, with an emphasis on agriculture. 


\section{Definition of a start-up}

Besides the interpretations of major scientists and personalities from the field concerned with enterprises, one can find various explanations on various webpages focused on the business environment and business success factors Fritsch and Schindele (2011) combine the concept of start-up with smaller start-ups that can according Luger and Koo (2005) be defined by three criteria: new, active and independent. Garret et al. (2009) add to this that businesses with an innovative orientation can utilise potential initial advantages, which they can create, and maintain the competitive advantage of the company.

Graham (2012) defines this start-up as follows: "A start-up is a company designed for rapid growth." Ries (2011), however, adds that bringing a new product or service into operation is possible only under conditions of extreme uncertainty. As shown by a survey by Ghosh and Nanda (2010) from Harvard Business School, $75 \%$ of all startups fail. Nesheim (2000) confirms this in his study, and states that at least 6 financed startups of 10 go bankrupt despite sufficient funds. A certain hope is mentioned by Nobel in his article (2011) - experienced entrepreneurs know that running a company which ultimately fails could in fact consequently be of benefit, but only if the managers are able to accept failure as potential for improvement.

According to the above-mentioned, one can declare that any newly-beginning business (mostly technologically focused) which solves problems locally and time-wise in an innovative manner can be a start-up.
Mueller et al. (2012) emphasise that the behaviour of incipient entrepreneurs varies significantly from the behaviour of an already-established business. According to these authors, incipient entrepreneurs spend an average of 11.8 hours daily at work and complete 94.8 different tasks. Kurke et al. (1983) agree with Mueller et al. in the opinion that a large number of actions (tasks) are typical for smaller businesses; in their survey, they demonstrated the inverse proportion between the size of a firm and the number of tasks. According to Korunka et al., (2003) start-up activities can be divided into two main kinds - cognitive and independent activities.

But one must emphasise the fact that a business plan which succeeded in undergoing all the phases of the project life is not considered to be a start-up. Start-ups can be financed internally (capital invested by the start-up members in the form of their own savings) or external capital (financial investment in return for a share in the start-up). Herman et al. (2012) state, in addition to this, that in $22 \%$ the start-up is financed by funds from family and friends, and $55 \%$ are formed by various types of investments. One of the funding options for start-up can be crowdfunding which Belleflame et al. (2014) defined as raising funds with the help of the Internet in the form of donations or in exchange for a good or voting rights. ESMA (2014) complements the definition as follows: "an open call to the public, typically through the internet, to finance a specific project".

\section{Conditions for start-up success and influencing factors}

Ries (2011) asserts that start-up success can be managed and learned. To explain the key start-up success factors, this author uses the following Fig. 1.

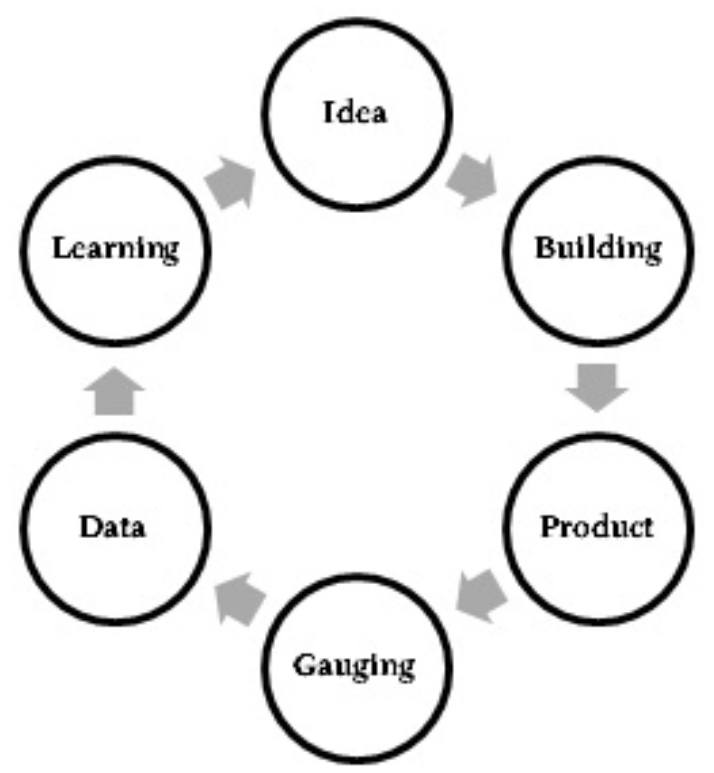

1: Key start-up success factors Source: Ries (2011) 
The word learning is of fundamental significance to Ries; in his concept it means beginning with a new idea, which Blank (2010) refers to as an entrepreneurial vision. Further, according to Ries, it is necessary to create a minimal product about which one can acquire the most data possible as to whether the proposed product is correct or incorrect. On the basis of the above-mentioned, an entrepreneur should learn and acquire new ideas (or keep the original successful one) and constantly continue in this cycle, until a complete entrepreneurial model is formed.

In the publication Strategies of the Blue Ocean, Kim and Mauborgne (2005) recommend focusing on markets which do not yet exist (and where there is thus no competition). They compare existing markets to red seas coloured with the blood of the competitive fight and new markets to blue seas. But they emphasise that new markets have not been probed. According to Kim et al. (2005), start-ups have to focus (besides other general success factors) on active learning - about markets, customers, their problems, marketing strategies etc.

Carter et al. (1996) advise individuals who are considering an enterprise to utilise opportunities aggressively in the short-term horizon. According to these authors, it applies that entrepreneurs who do not devote enough time and energy to business activities necessary for starting business are faced rather with prolonged efforts or actual failure than with success. In this regard, the very personality of start-up founders is an entirely essential concept, whilst Rauch and Frese (2000), for instance, pose two quite fundamental questions:

1. Can start-up founders generally be described with the aid of certain personality traits?

2. Can a direct connection with entrepreneurial success be detected in these characteristics?

Numerous professional studies then focus on the specific elements of given types of entrepreneurs, whilst Frank, Lueger and Korunka (2007), for instance, in connection with start-up enterprises, characterise these elements as a need to achieve results/successes, the so-called management centre of gravity, i.e. the extent of individuals' convictions as to their abilities to control the results of the activities and willingness to undergo risks. The stated characteristics of start-up founders is likewise connected with their age, whilst Elias and Purcel (2003), for instance, consider it a worldwide trend that start-ups are to a large extent established primarily by secondary school and especially higher education graduates. Nor can the influence of gender be overlooked. Johansen (2013, p. 218) presents the difference of various barriers to start-up enterprises in connection with the gender of their founders:

1. Gaining institutional support, family support and/or securing funds appear to be a more significant problem in relation to women (Heilman and Chen, 2003, Shinnar et al., 2012).
2. Fear of failure is more marked in women than among men (Langowitz and Minniti, 2007, Wagner, 2007).

3. It is more difficult to perceive women than men as entrepreneurs (Kirkwood, 2009)

Directly in connection to the given type of enterprise in the CR, Kessler (2007, p. 398) also highlights two attributes which, according to his survey results, most significantly influence the future success of an enterprise. These are indeed aspects concerning the entrepreneur's personality and, further, the resources the entrepreneur has at his disposal in the beginning. The problem of lack of resources, especially financial, subsequently has an influence on the further course of the enterprise. Cabral and Mata (2003), for instance, prove that an insufficient amount of funds precludes entrepreneurs, in the beginnings, from achieving the size of firm that would be appropriate or necessary for the given enterprise. Džupka, Klasová and Kováč (2016, p. 42) state specific means of possible start-up financing. Classic bank loans, risk capital, structural funds or so-called business angels (individual investors with their own capital) are at issue. Among the criteria according to which investors decide it is especially the team, the product itself, the market and the strategy used (Agha, 2014).

People are a further source that cannot be omitted. A fundamental aspect of a start-up is to have the right team of people with various skills. Shepherd et al. (2000) place emphasis on the quality of human capital especially in incipient firms. As stated by Colombo et al. (2004), in a real start-up an entrepreneur has to choose his partners and employees well so as to secure sustainable growth. Hiam (2003) stated and analysed 15 sources of motivation for work in start-ups: affiliation to a group, the possibility of self-fulfilment, an endeavour to succeed, the need for stability, career growth, enthusiasm from new experiences, status achievement, the need for usefulness of work, recognition, the possibility to compare oneself with others, a friendly atmosphere, the possibility of autonomy, financial remuneration, a personal and individual approach. According to Hiam (2003), partners have to complement one another and every team has to have someone who will not only program and sell, but also present the firm correctly. The strength of a team is enormous if important persons are engaged in the entire start-up operation. One can work with external consultants, but they cannot have the understanding of the team players of the firm who work in it. It is important to create a company culture and cooperation, where all team members will observe their contribution for business and provide feedback. In this case it is suitable to avoid directive management. On the contrary, it is good to focus on the fact that every member's voice can be heard.

If it occurs that an idea is not transformed into realisation, it is still only an idea that is at issue. Senor et al. (2009) define a start-up as a smaller 
business developing an innovation with great commercial potential. The authors emphasise innovativeness which, however, need not necessarily lie in the development of an entirely new technologies. Nevertheless, especially in sectors with high technological demands, in the so-called high-tech sector, innovations are an entirely essential success factor (Chorev and Anderson, 2008).

An entrepreneur has to believe in his idea; only then will he be able to convince interested parties. Once intense work begins on an idea it becomes a project. If the entrepreneur does not believe in a project, he will not receive support from an investor. If the entrepreneur is able to offer something which has true value, the market itself usually rewards it. In this connection, Paradkar, Knight and Hansen (2015) emphasise the significance of alliance and cooperation with other, already existing firms and other partners, which can markedly aid the success and competitiveness of the start-up enterprise.

Start-ups should invest into ERP (Enterprise Resource Planning) solutions, data storages and into business intelligence instruments rather than into PR (Public Relations) and advertising. Hartmann et al. (2016) have confirmed the importance (at the beginning of an enterprise) of this element, information, and highlight the connected ability to utilise it adequately.
In his research, Agha (2014) compiled a total of seven categories which have an influence on the success of a start-up: preparation, the team, the idea/product, financing, aiming, the realisation as such and external factors. The following were identified as the most important specific factors from these groups: the personality of the entrepreneur and the members of his team, the scalability/extensibility of the product of business (so-called scalability), the product itself, timing, company culture or the business model used.

All the above-mentioned attributes could subsequently have an influence on so-called start-up speed, when this problem presents a timeframe between the actual enterprise conceived and achieving the first results created by the business (Hechavarría, et. al., 2016, p. 137).

\section{MATERIALS AND METHODS}

In the theoretical part of the work, the method of analysing secondary sources was used, on the basis of a literature summary was compiled. It was especially articles from the ProQuest and Scopus databases that were used, and then further, verified internet sources with authors with an adequate level of expertise in the given area. Primarily logical scientific methods of comparison, synthesis,

\section{I: List of questions posed}

1. Could you please state the following identifying data? A. gender, B. your age when establishing the start-up, C. highest completed education, D. official name of your firm, E. year of start-up establishment.

2. The idea from which your start-up originated. Was it entirely your own? How did the realisation of this idea proceed? Why are you interested in the area of agriculture/food/nutrition in particular?

3. Did you struggle with fear of failure? In this regard, in what manner did you work with time management?

4. How and with what sources did you acquire data and information? Were you able to work with the data? Did you face any obstacles in the course of realisation? What were they?

5. How was your product or service prepared or developed? In what manner was the design elaborated?

6. Did you conduct an analysis of the competition in your chosen field of activity?

7. In what manner did you identify your customers and aim towards them? Did you monitor their behaviour? Did you have sufficient information from previous surveys?

8. Did you have the possibility to test human resource management at any time prior to your enterprise? Are you currently faced with problems of people management? Are you faced with alteration of generations?

9. In what manner did you ascertain the possibility of financing your enterprise? What possibility did you finally choose? Did you approach investors and other cooperating subjects? Were you a part of an entrepreneurial incubator or accelerator etc. or did you participate in a competition?

10. Did you have your own set vision and goals? Did you fix your business model?

11. Did you gauge your success with an indicator?

12. Was the required size of business attained from the outset?

13. Was the business culture in your start-up built in a pointed manner?

14. What is your view on diversity management? Do you know the motivation of your employees for working for your business at that time? Please specify. Did you or do you utilise external consultants? What activity do they secure?

15. Were you supported in your surroundings? Were you able to argue and explain your intentions to your surroundings?

16. When you examine the areas handled above - what was your awareness of these aspects based on knowledge you had acquired during your studies? Do you consider the acquired fundamentals adequate or did you lack education in some of these areas? In the second case, please give the most specific examples possible.

17. If you were part of an entrepreneurial incubator or accelerator, did the incubator/accelerator compensate for certain information you lacked from your secondary/higher education? 
deduction and induction were used when compiling the literary summary. In view of information from the representatives from the Ministry of Agriculture, that the area of agricultural start-ups has not been monitored officially and there is therefore no official list thereof, the method of intentional selection (see description below) was used. Very little information on official lists of agricultural start-ups has also been obtained in foreign sources. For example, Sorvino (2017) lists the 25 most innovative agricultural-start-ups, a similar list can be found in India (AngelList, 2018). Similar lists, whether official or private, are unfortunately not available.

For collection of primary data, we used the method of questioning, the technique of structured interviews, for which questions from the presented theoretical departure points were extracted. A list of basic questions posed is given below. First, identifying questions, and then specific questions concerning the establishment of the start-up were posed, see Tab. I below.

21 informants from the Czech Republic, whose entrepreneurial activity was connected with the monitored area, were selected for participation in the survey. The approached respondents had, in the last 5 years at most, established start-up enterprises, whilst they themselves had been the basic driving force behind this establishment. At the beginning of the research, the Ministry of Agriculture was contacted asking whether it was registering start-ups in the monitored areas, with the authors being given a negative answer. Subsequently, Nutrition, Food, Agriculture, and Key-word Start-up keywords were added to Google's search. Business incubators and accelerators were also monitored and relevant stakeholders sought. The research sample included organizations operating in selected areas, which themselves referred to as start-ups. Subsequently, several other companies from the chosen field were searched, for which the founders were identified and their characteristics as well as the attributes of the companies themselves were assessed. It was determined whether they corresponded to the theoretical concept of start-up business. The final confirmation of the correctness of the selection was left to the representatives of the companies contacted, who were to evaluate whether they were among the start-ups according to the definitions below. In view of the heterogeneity of the understanding of the term start-up, the respondents were presented with the following general definitions of start-ups, and it depended on them as to whether, according to the content thereof, they classified their enterprise as being among start-ups.

- A start-up is a people-formed institution designated to create a new product or service under extremely uncertain conditions.

- For a start-up, the most typical characteristic should not be that it is a newly-established firm, but that it is a firm which approaches the market with great plans and ambitions. Ambitions to bring something new, innovative and different to the market. Ambitions to become a leader on the global scale. Ambitions to help people solve a certain problem. Start-ups, in brief, are young companies which in a certain sense want to change to world.

- A start-up is a company which works on the solution of a problem which is not entirely clear and success is not guaranteed.

- A start-up is a firm, usually a business which is attempting an innovation which in most cases fills a gap in the market - it thus works with a new product on an unknown market.

In view of the great workload of the approached informants, the structured interviews were held in electronic form, where the informant was sent the basic set of questions specified above. After about two weeks, the informants were likewise contacted by telephone with a repeated request to complete the questionnaire. The final result was that 6 completely filled questionnaires from a total of 21 respondents (via e-mail and telephone) were acquired. A total of 6 refusals due to time constraints came and 9 organisations did not react at all despite all telephone and e-mail reminders. As a reason for refusing to participate in research, workload has been reported in most cases.

The start-ups which did participate in the survey can be characterised as follows: There were 6 firms, whilst 5 of them were established in 2015, the fifth at the turn of $2013 / 2014$. As regards the exact focus of enterprise, three start-ups focused on crop, flower/plant cultivation, a start-up which brought into operation a mobile and web application connected with farming, and a subject which designs specific vitamin supplements were surveyed. Four of the approached start-up founders had completed secondary education with A-levels, two had completed higher education. 3 men and 3 women reacted to the questions asked, whilst the age when establishing the start-up ranged from 21-38.

The acquired information was processed primarily with the aid of logical scientific synthesis methods, and based on the connection of all parts of this study the resultant recommendation was drawn. At the close of the work, the most important insights were summarised, the utilised method was primarily the scientific method of synthesis mentioned above.

\section{RESULTS}

The acquired results of the qualitative study brought interesting results, whilst a synthesis thereof is presented below.

The approached respondents agreed that the idea, from which the start-up originated was their own, mostly based on a positive attitude towards agriculture and family tradition. They thus wanted to support their hobbies and pastimes in the context of an enterprise, in which they eventually 
succeeded. One respondent also said that he has been in the beekeeping business for three years. Also in this case, the family tradition continues, but they want to combine the fields of physiotherapy with bee venom treatment.

The opinions of the respondents as to fear of failure can be summarised in two statements: (1) "I consider entry into the absolute unknown to be the greatest challenge and obstacle at the same time" and (2) "Fear has come only in the last few years, with the increase of loans, employees and obligations". According to the respondents, fear of failure is connected not only to the beginnings of an enterprise, but one practically has to take it into account at all times. On the contrary, it is increasing (or reappearing) with the growing number of liabilities, financial investments and invested energy, etc. Likewise, the problem of time management is a repeating, problematic theme. The respondents are aware of the necessity of effective time management, although they also admit to their limitations in this area. Another respondent to this question, concerning barriers to doing business, states: "I would also like to add that many start-ups would welcome a seminar on the subject of grant titles, their search and drafting of the application. At all, financial literacy, current laws, and their changes, I see as one of the most important sources of education."

As expected, the main primary sources for the respondents were the internet and professional books; but further, also knowledge from practice, various types of training or professional consultations at the State Agricultural and Food Inspection and other professional organisations. Thus on the one hand, the pertinent authorities functioned as an information source; on the other hand, it was indeed the connected bureaucracy and the time-consuming nature thereof that was mentioned as being one of the greatest obstacles to the enterprise. In the course of the realisation of the project, the respondents were faced with other obstacles, such as insufficient investments, disagreements in the team and other personnel problems, administration, restrictions connected with marketing and dispatching etc. An interesting approach to the obstacles in enterprise can be illustrated in a statement given by one of the respondents: "This is why I wouldn't even refer to them as obstacles, but rather points to be solved". Another respondent to the above stated that he sees all obstacles as a challenge and a competitive advantage.

In answer to questions as to how the product or service was prepared or developed and in what manner the proposal was elaborated, the respondents diverged slightly in their respondents. The first part of the respondents stated that the realisation of the start-up as such was a spontaneous and fast action on the basis of their own ideas and thoughts; in contrast to this, the second part of the respondents stated that it was necessary to process everything carefully on an intangible level (fixing a vision, the potential customer, space on the market), but also on a practical level (the product as such, marketing, price, the way to the customer, propagation, among others). According to the respondents, foreign products on the same basis and scientific studies can also be considered a source of inspiration. Against this, respondents agreed that they believe that a high-quality natural product will help them grow demand.

It is interesting that despite the fact that the majority of conventions speak of the necessity to analyse the competition prior to establishing an enterprise, it has transpired in practice that the questioned start-up founders do not consider this step necessary. The majority did not conduct an analysis of the competitive environment, and if so, this was rather to gain basic knowledge of the competition on the market. Contrariwise, the competition, its influence and market changes have been noticed by the informants after their organisations have been operating for a longer time. There was also the view that it is better not to research this area too much initially, and there are two reasons for this: Firstly, because the reality and the development thereof fluctuate and it is unpredictable to such a degree that researching the competitive situation is entirely needless. The second reason was that knowing the real market situation could discourage numerous incipient entrepreneurs.

As regards the identification and recognition of the behaviour of target customers, the questioned start-up founders are not advocates of broad and in-depth consumer/customer surveys. In their words, the target group for a given product/service, especially thanks to communication on social networks, has found the given firm on its own. In this regard, one must add that all six questioned startups has an established Facebook profile and utilise it for regular communication with the target customer group. Only one of the firms subsequently gauges customer satisfaction in the form of a quantitative questionnaire survey.

All respondents stated identically that they have had experience with managing human resources in the context of their start-ups, albeit each at a different level. In the context of smaller startups, respondents prefer outsourcing in the context of activities; in larger start-ups, they already have their employees. A positive finding stemmed from the results, that in the context of the monitored start-ups, they support employment in all age categories, they do not struggle with problems of generational alteration, for there is interest on the parts of young and older employees, whilst they emphasise patience.

We can agreed with Wilden et al. (2010) that it is important to support strategic investments in the recruitment of suitable qualified human resources in all sector including agriculture and support employer branding of agricultural companies. 
Among individual start-ups, securing the financing for the enterprise likewise took place in several ways, but primarily from their own funds, and further in the form of loans from both persons close to them and banking institutions. None of the questioned subjects was a part of an entrepreneurial incubator or accelerator, but three of the projects successfully participated in three various competitions - Rozjezdy roku (Takeoff of the Year) by T-Mobile, Start-up Harvest or the competition in Impact Hub Praha, where they gained financial or other support. In the case of the Start-up Harvest competition, for instance, the path towards successful enterprise was aided both by an investor and a foreign business mentor, whose contribution is evaluated by a founder as being the most significant. The popularity and also positive influence of entrepreneurial incubators/accelerators, however, has been confirmed by practice (e.g. Viturka, 2010; Vojík, 2010), both by their very number and by the number of successfully supported projects. As an example, one can mention, for instance, the VUT Technological Incubator, the VŠB - Technical University of Ostrava Centre of Innovation Support, Inovacentrum, xPORT VŠE or other means of support, such as financial support by Start-up VŠEM etc. Four of the five approached start-ups do not currently work with any investor; on the other hand, they utilise or intend to utilise pertinent grant opportunities.

One of the basic commercial conventions which have already been presented in the theoretical part was that at the start, each enterprise should have fixed a certain business model, a clear vision and enterprise goal. But the replies gathered in the context of this survey show a certain variety of approaches in this area. On the one hand, two approached start-ups had fixed, when establishing, a very clear vision which they have constantly followed. Contrariwise, another three start-up founders did not initially have a self-contained and clear idea towards which they wanted to aim, and that vision and business model shaped itself over several years. The last questioned start-up founder entered into business with a certain vision which, however, gained its final form after a year of the functioning of the firm, and a further change thereof was acknowledged. But what connected almost all the answers was the awareness that the goal and vision of the firm has to be corrected according to the wishes and requirements of the target group.

In the beginnings of the enterprise, no clear and specific indicators had been set among the informants to gauge the successfulness of their enterprise. Only with the take-off of these startups and longer-term operation on the market did the respondents begin to become aware of the necessity and need for closer monitoring of the given area. The predominant monitored indicators are, for instance indicators on social networks, the numbers of assignments, client structure, market share, repayment of loans for starting the enterprise etc. In one case, the firm had already after one year measured the exact percentage of new customers, cohorts according to months, retentions and several other indicators.

Four out of the six questioned start-ups had a major problem acquiring the necessary number of able workers. Moreover, with the growth of the firm, this problem has repeated itself in a certain way and firms thus try to adapt, from the perspective of human resources, to the needs of the target market. From the responses, furthermore, it is clear that start-up founders are aware of the importance of the right and able employees and also the lack thereof. One can here observe a connection both with the currently high level of unemployment and with the general lack of candidates for work in agriculture and other connected fields.

The respondents agree that, in the beginnings of the enterprise, they did not set for their firms a clear orientation connected with a business culture, and the formation there of was a more or less natural and spontaneous process. They do not devote closer attention to planning a business culture especially for lack of time. The importance thereof has been highlighted in two cases: firstly, during the growth and expansion of the firm and thus with a larger number of employees; and further, with the extension of the firm outwards (with clients, stakeholders etc.).

We can summarized that Ambler and Barrow (1996) state that organisational brands communicate the benefits of using a product or service to potential consumers, employer brands communicate the benefits of employment to potential employees and it is important nowadays what is in agreement with the results. The main role of the employer brand was according to Barrow and Mosley (2006) to provide a coherent framework for management to simplify and focus priorities, increase productivity and improve recruitment, retention and commitment in all sector of economy, agriculture included.

Last, but not least, the problem of employees, their motivation, utilisation of external consultants and diversity management generally was surveyed. The respondents' replies were markedly divergent and one can draw from them only a generally valid conclusion: The worker composition depends on numerous factors, such as the specific activity of firm, its size, financial background etc. The approached start-ups mostly do not use the services of external consultants, only in certain specific cases (e.g. coaches, programmers, business mentor etc.) and this is especially due to insufficient firm size. Likewise, it does not follow from the responses that a limitation of selection in connection with employees is set; on the contrary, diversity is supported.

The questioned start-up founders felt, in the beginnings of their activity, great support from those close to them, both thanks to the ability to 
reason and thanks to their own enthusiasm for a given thing, by which they likewise won over their surroundings. Only in one case was a certain form of scepticism mentioned, which was, however, overcome through the above-mentioned approach.

The respondents univocally agreed that the currently adjusted system of education at higher education facilities is not entirely suitably adjusted to support start-up establishment and gaining the knowledge and experience for the management thereof. Constant education is necessary - in the form of books, courses or, as the case may be, thematic blogs on the internet, for there is a lack, for instance, of certain exact education in the areas of gardening, botany and floristics. The approached respondents see a necessity for support of practice during studies.

In view of the fact that none of the start-ups which participated in the survey had been a part of an entrepreneurial incubator/accelerator, it is not possible to monitor the influence of the support mechanisms for entrepreneurial success or the level of their substituting classic school education.

\section{DISCUSSION}

Education and consultation support of innovation in the area of means, management and technology, strengthening of monitoring and development of information systems including marketing support and awareness-building in agricultural practice is one of the main strategic directions of agriculture as a whole in the Czech Republic. Despite the fact that start-ups in the area of agriculture have not officially been probed, they can be identified, and at the same time their success factors can be discussed. It is a question as to whether they are new approaches or innovations to current processes; in any event, it all contributes to increasing the competitiveness of agricultural businesses in the Czech Republic and abroad.

As stated by the strategy of the Ministry of Agriculture, with a horizon until 2030, it is necessary to view the agricultural sector as the largest "manager" in the region and assess the economic and social significance thereof not only in the context of production, but also in the context of extra-productive and region-forming functions. Agricultural land resources, taking up $54 \%$ of the republic area value, represent a space for the environment, land formation and recreational potential used especially by the urban part of the Czech population and, last but not least, also the possibility for constant development of the agricultural area in the context of creating innovations and start-ups, which have hitherto been relatively few in comparison to other sectors. Based not only on the strategy of the Ministry of Agriculture CR, but also results gained by research, for instance, by Ruiz-Garcia et al. (2016), Whitehouse et al. (2014) or Salgado et al. (2013) and others, it can be summarised that agriculture is among the strategic sectors of the national economy, although constant emphasis has to be placed on education the broad public, in which potential start-up founders, whether more or less successful, can be found.

With reference to the main aim of the paper, the recommendations for educational institutions can be summarised into the areas stated below. First and foremost, educational institutions should focus on courses in the area of increasing the efficiency of a manager's work through correct planning and time usage and development of the competencies of his teams and through delegation. It is necessary comprehensively to focus on the problem of self-management and life-management, which would contribute to prevention of the burnout and workaholic syndrome and towards building a healthy lifestyle. One can recommend a smaller group of university students, through which expected interaction with the students will occur. It is suitable to combine several teaching techniques, such as seminar instruction, a lecture with a discussion, and a lecture with activation or group instruction. Experienced guests, who are able to explain the connection of theoretical instruction at schools with real establishment of an enterprise, could be invited to lectures.

Last but not least, on the basis of the submitted literature it is necessary to increase awareness of the existence of incubators or accelerators etc. (the contribution and significance of engaging in various competitions has been proven by own research), especially in relation to higher education facilities. These programs offer start-up management, aid with business models and strategies, and their main aim is to lead start-ups to success not only with an investor.

Everyday reality also proves that financial education is necessary. The initial insight into the problem of financial literacy is provided by teaching of obligatory professional subjects where the lecturers update the educational content with regard to legislative changes, tax or interest rates, the suitability of financial products etc. A broad spectrum of methods is generally applied in the instruction. The significance of financial education is increased in direct proportion to the increasing number of financial market products and the general financial globalisation of the economy. Promoting the emergence (and development) of new firms, especially small and medium-sized ones, is a major tool of cohesion policy that strengthens regional economies. There are countless programs in the Czech Republic providing grants to various business areas. Respondents agreed that it would also be appropriate to include education in the field of grant titles, their search and the drafting of applications. In this regard it has been constantly mentioned the issue of bureaucracy as a major obstacle to new entrepreneurs. 


\section{CONCLUSION}

The results have shown that start-ups in the context of agriculture, food and nutrition are appearing increasingly in practice. However, everyone approaches start-up establishment differently; some place emphasis on preparedness and premeditation; others, by contrast, on speed of realisation. In summary, it can be said that the respondents consider the entry into the unknown to be the greatest advantage and disadvantage, and that fear of failure in the context of an enterprise in the area of agriculture, food and nutrition has arrived only in the last few years, when loans, employees and obligations are on the rise. The respondents and their start-ups will gain the opportunity of better presentation towards potential employees in agriculture, which has been long considered a sector in which it is difficult to attract and retain creative employees.

The article is focused on a specific sector - a primary sector (agriculture), whilst a relatively small selection set was worked with. The results can be presented as results of case studies in start-up establishment, and they can help others who are considering establishing a start-up in agriculture. The authors are aware of the limits of the presented study, which lie in the small number of respondents and the specific business areas. Yet even despite personal contact, it was not possible to gain a larger number of informants from the selected basic set. Despite this, however, one cannot overlook the fact that to this day, no similar survey has been carried out in the conditions of Czech Republic, which is why the authors are of the impression that the acquired information can benefit for other incipient entrepreneurs.

Acknowledgements

This paper was supported by CES VŠEM (Project GCES08, „Mind Power“).

\section{REFERENCES}

AGHA, N. 2014. Success Factors of Startup Companies. An Empirical Analysis of E-Business Startups in North America. Munich: GRIN Publishing.

AMBLER, T. and BARROW, S. 1996. The employer brand. Journal of Brand Management, 4(3): 185-206.

ANGELLIST. 2018. Agriculture Startups. [Online]. Available at: https://angel.co/agriculture [Accessed: 2018, May 28].

BELLEFLAMME, P., LAMBERT, T. and SCHWIENBACHER, A. 2014. Crowdfunding: Tapping the right crowd. Journal of business venturing, 29(5): 585-609.

BLANK, S. 2010. What's A Startup? First Principles. [Online]. Available at: steveblank.com/2010/01/25/whats-astartup-first-principles/ [Accessed: 2017, October 24].

BLANK, S. 2013. Why the lean start-up changes everything. Harvard business review, 91(5): 63-72.

BARROW, S. and MOSLEY, R. 2006. The employer brand: Bringing the best of brand management to people at work. Chichester: JohnWiley and Sons.

CABRAL, L. and MATA, J. 2003. On the evolution of the firm size distribution: Facts and theory. The American Economic Review, 93(4): 1075-1090.

CARTER, N. M., GARTNER, W. B. and REYNOLDS, P. D. 1996. Exploring start-up event sequences. Journal of business venturing, 11(3): 151-166.

COLOMBO, M. G., DELMASTRO, M. and GRILLI, L. 2004. Entrepreneurs' Human Capital and the Start-up Size of New Technology-Based Firms. International Journal of Industrial Organization, 22 (8- 9): 1183-1211.

DŽUPKA, P., KLASOVÁ, S. and KOVÁČ, V. 2016. Analysis of Innovative Start-Up Companies-Case of Košice Region. Quality Innovation Prosperity, 20(1): 40-56.

ELIAS, P. and PURCELL, K. 2003. On higher ground. People Management, 19(11): 24-31.

ESMA. 2014. Position Paper „Crowdfunding“. [Online]. Available at: www.esma.europa.eu/sites/default/ files/library/2015/11/2014-smsg-010.pdf [Accessed: 2017, October 21].

FORBES. 1976. The Unfashionable Business of Investing in Startups in the Electronic Data Processing Field. Forbes, 6(2).

FRANK, H., LUEGER, M. and KORUNKA, C. 2007. The significance of personality in business start-up intentions, start-up realization and business success. Entrepreneurship and Regional Development, 19(3): 227-251.

FRITSCH, M. and SCHINDELE, Y. 2011. The Contribution of New Business to Regional Employment - An Empirical Analysis. Economic Geography, 87(2): 153-180.

GHOSH, S. and NANDA, R. 2010. Venture capital investment in the clean energy sector. Boston: Harvard Business School.

GRAHAM, P. 2012. Want to start a startup? Get funded by Y Combinator. [Online]. Available at: http://www. paulgraham.com/growth.html [Accessed: 2017, October 14].

HARTMANN, P. M., ZAKI, M., FELDMANN, N. et al. 2016. Capturing value from big data - A taxonomy of data-driven business models used by start-up firms. International Journal of Operations and Production Management, 36(10): 1382-1406. 
HECHAVARRÍA, D. M., MATTHEWS, C. H. and REYNOLDS, P. D. 2016. Does start-up financing influence start-up speed? Evidence from the panel study of entrepreneurial dynamics. Small Business Economics, 46(1): 137-167.

HEILMAN, M. E. and CHEN, J. J. 2003. Entrepreneurship as a solution: the allure of self-employment for women and minorities. Human Resource Management Review, 13(2): 347-364.

HERMAN, B. L., MARMER, M., DOGRULTAN, E. et al. 2012. Startup Ecosystem Report Part 1. [Online]. Available at: reports.startupcompass.co/StartupEcosystemReportPartlv1.2.pdf [Accessed: 2017, October 09].

HIAM, A. 2003. Motivational management: inspiring your people for maximum performance. London: AMACOM.

CHOREV, S. and ANDERSON, A. 2008. Success Factors for High-Tech Start Ups: Views and Lessons of Israeli ExpertsSchaul Chorev and Alistair AndersonSuccess Factors for High-Tech Start Ups: Views and Lessons of Israeli Experts. In: GROEN, A., SIJDE P. V. D., OAKEY, R. et al. (Eds.). New Technology-Based Firms in the New Millennium. Emerald Group Publishing Limited, pp. 239-259.

JOHANSEN, V. 2013. Entrepreneurship education and start-up activity: a gender perspective. International Journal of Gender and Entrepreneurship, 5(2): 216-231.

KESSLER, A. 2007. Success factors for new businesses in Austria and the Czech Republic. Entrepreneurship and regional development, 19(5): 381-403.

KIRKWOOD, J. 2009. Is a lack of self-confidence hindering women entrepreneurs? International Journal of Gender and Entrepreneurship, 1(2): 118-133.

KORUNKA, C., FRANK, H., LUEGER, M. et al. 2003. The entrepreneurial personality in the context of resources, environment, and the startup proces - A configurational approach. Entrepreneurship theory and practice, 28(1): 23-42.

KURKE, L. B. and ALDRICH, H. E. 1983. Mintzberg was right: A replication and extension of the nature of managerial work. Management Science, 29(8): 975-984.

LANGOWITZ, N. and MINNITI, M. 2007. The entrepreneurial propensity of women, Entrepreneurship Theory and Practice, 31(3): 341-364.

LUGER, M. I. and KOO, J. 2005. Defining and Tracking Business Start-ups. Small Business Economics, 24(1): 17-28.

MUELLER, A. B., VARKEY, K. T. J., COVIN, J. G. et al. 2012. Pioneering orientation and firm growth: Knowing when and to what degree pioneering makes sense. Journal of Management, 38(5): 1517-1549.

NESHEIM, J. L. 2000. High tech start-up: the complete handbook for creating successful new hightech companies. New York: Free Press.

PARADKAR, A., KNIGHT, J. and HANSEN, P. 2015. Innovation in start-ups: Ideas filling the void or ideas devoid of resources and capabilities? Technovation, 41(7): 1-10.

RAUCH, A. and FRESE, M. 2000. Psychological approaches to entrepreneurial success: A general model and an overview of findings. International review of industrial and organizational psychology, 15: 101-142.

RIES, E. 2011. The lean startup: how today's entrepreneurs use continuous innovation to create radically successfulbusinesses. New York: Crown Business.

RUIZ-GARCÍA, A., RUIZ-SAAVEDRA, E. and FEO-GARCÍA, J. 2016. Start-up of brackish water desalination for agricultural irrigation in the Canary Islands (Spain). Desalination and Water Treatment, 57(48-49): 22734-22742.

SALGADO, B., MAJAMAA, K., SANZ, J. et al. 2013. Design and start-up experiences of 19,000 m3/d Camp de Tarragona-Vilaseca Water Reclamation Plant. Desalination and Water Treatment, 51(7-9): 1519-1526.

SENOR, D. and SINGER, S. 2009. Start-up Nation. Toronto: McClelland and Stewart.

SHEPHERD, D. A., DOUGLAS, E. J. and SHANLEY, M. 2000. New Venture Survival: Ignorance, External Shocks, and Risk Reduction Strategies. Journal of Business Venturing, 15(5): 393-410.

SHINNAR, R., GIACOMIN, O. and JANSSEN, F. 2012. Entrepreneurial perceptions and intentions: the role of gender and culture, Entrepreneurship Theory and Practice, 36(3): 465-493.

SORVINO, C. 2017. The 25 Most Innovative Ag-Tech Startups. [Online]. Available at: https://www.forbes. $\mathrm{com} /$ sites/maggiemcgrath/2017/06/28/the-25-most-innovative-ag-tech-startups/\#d71ff9b48830 [Accessed: 2018, May 28].

VITURKA, M. 2010. Quality of the Business Environment, Regional Competitiveness and Regional Development Strategy of the Czech Republic [in Czech: Kvalita podnikatelského prostředí, regionální konkurenceschopnost a strategie regionálního rozvoje České republiky]. Praha: Grada Publishing.

VOJÍK, V. 2010. Specifika podnikání malých a středních podniků v tuzemsku a zahraničí. Praha: Wolters Kluwer Česká republika.

WAGNER, J. 2007. What difference a Y makes - Female and male nascent entrepreneurs in Germany. Small Business Economics, 28(1): 1-21.

WHITEHOUSE, N. J., SCHULTING, R. J., MCCLATCHIE, M. et al. 2014. Neolithic agriculture on the European western frontier: the boom and bust of early farming in Ireland. Journal of Archaeological Science, 51(6): 181-205.

WILDEN, R., GUDERGAN, S. and LINGS, I. 2010. Employer branding: Strategic implications for staff recruitment. Journal of Marketing Management. 26(1-2): 56-73. 


\section{Contact information}

Helena Smolová: helena.smolova@vsem.cz

Pavla Kubová:pavla.kubova@vsem.cz

Hana Urbancová: urbancova.hana@uzei.cz 